\title{
Voters' Perception about Money Politics in the 2020 Local Leaders Election in Central Java during the Pandemic
}

\author{
Neny Marlina ${ }^{1}$, Priyatno Harsasto ${ }^{2}$ Supratiwi $^{3}$ \\ \{marlina.neny2011@gmail.com ${ }^{1}$ \} \\ Universitas Diponegoro, Indonesia ${ }^{1,2,3}$
}

\begin{abstract}
Since the first simultaneous elections in 2005 until now, there has been no escape from potential conflicts and fraud. Also, elected regional heads who are directly elected by the community to be able to accommodate the interests and needs of the local community are commonly involved in corruption cases. One of the insanity violations in the implementation of concurrent elections in 2020 is the political practice of money used to attract votes. This condition is also more complicated by the Covid-19 pandemic that caused an economic crisis in the community as well as being a loophole for the political rise of money in organizing elections. The difficulty of the economic condition of society can be used as the right momentum for the political practice of money. This condition is interesting to see about the public's perception of money politics in the 2020 Concurrent Elections amid the Covid-19 pandemic. The result of this study is that the Covid-19 pandemic did not discourage the interest and desire of the public to continue to exercise their voting rights in the 2020 concurrent elections to be held on December 9. This shows that voter participation in the 2020 concurrent elections is not to be feared but the need for attention is that the public has realized that the condition of the Covid-19 pandemic has given great space for the political practice of money.
\end{abstract}

Keywords: Regional Heads Election, Money Politics, Pandemic

\section{Introduction}

The implementation of elections in both provinces and districts, technically, is not as complicated as the 2019 Concurrent Elections. However, the election is relatively more sensitive than the national elections. This is because the election of regional heads has a higher potential for conflict than elections and legislative elections. The emotional factor between the electorate and who to choose tends to be stronger because it assumes that the regional head can accommodate the interests of the electorate. Elections are not only seen from a technical point of view or the process of converting votes into seats alone. But it became an arena that connected communities in the area framed by the resulting relationship of representation and public policy [1]. This means that the regional head of elected election results must be able to answer various challenges as well as the needs of the people in the region. On the other hand, the results of concurrent elections in 2015 showed that the elected regional head was unable to win majority support in the Provincial Parliament or the District/City Parliament. Whereas in almost every decision and policy decision, the head of the region will be in direct contact with the local legislature. 
In 2020 there will be simultaneous regional head elections in 270 regions. The 270 areas have details, 9 of which are provinces, 224 districts, and 37 cities. The 2020 concurrent elections were supposed to be followed by 269 regions, but it became 270 because the Makassar City Election was repeated. Central Java is one of the provinces that held simultaneous elections that will be held in 21 districts/ cities with a total budget of 687,9 billion which is nationally amounting to $8 \%$ of 9.9 trillion. With the budget and number of districts/cities that hold concurrent elections, Central Java Province has its uniqueness to research [2]. Although the implementation of simultaneous elections 2020 in Indonesia is not new but does not mean the implementation of elections becomes minimal conflict and cheating. Elections are part of a democracy that upholds people's sovereignty as the ultimate power. Dahl explained that democratic governance is a prerequisite for facilitating freedoms that provide the public with the opportunity to determine its destiny under the umbrella of applicable law [3].

Since the first simultaneous elections in 2005 to 2017 have not escaped the potential for conflict and fraud. Also, elected regional heads who are directly elected by the community to be able to accommodate the interests and needs of the local community are commonly involved in corruption cases. In Indonesia Corruption Watch (ICW) records, during 20102017 there were at least 215 regional heads suspected in corruption cases handled by law enforcement ranging from project budget games to bribery handling cases. This indicates that the dynamics of the selection of regional heads directly and simultaneously do not necessarily eliminate the practice of cheating either in the process of introducing candidates until after the appointment of the regional head [4]. Election organizing has several other problems that usually occur, namely candidate buying between candidates and political parties, the emergence of problematic names (ex-convicts or corruption suspects) and candidates with dynasties, the emergence of a single candidate, High-cost campaigns, illegal capital collection, and politicization of government programs for campaigns, Politicization of bureaucracy and state officials, Political money, and Manipulation of campaign fund reports. One of the insanity violations in the implementation of concurrent elections in 2020 is the political practice of money used to attract votes. In the 2017 concurrent elections, Bawaslu found 600 cases of alleged political money both during the campaign, the introduction of candidates, and in quiet times in the 101 regions that held elections [4][5].

Based on the political case of the money, central Java did not escape the insanity of money politics in the run-up to the 2020 concurrent elections. This condition is also further complicated by the Covid-19 pandemic that caused an economic crisis in the community. The central Java government said that the Covid-19 virus resulted in Covid-19 positive patients in Central Java on Thursday, July 30, 2020, increasing by 161 people or the third-largest number of Covid-19 positive patients daily in Indonesia after DKI Jakarta which accumulatively reached 9,281 cases. Besides, the Covid-19 Management Task Force created a mapping of risk zoning at the Regency/City level in Central Java Province (Jateng), out of 35 districts/cities 3 areas enter the red zone or high-risk zone and 21 areas enter the medium or orange risk zone [6]. It is this condition that causes a gap for the political rise of money in organizing elections. The difficulty of the economic condition of society can be used as the right momentum for the political practice of money. This is also coupled with a new normal policy that provides wiggle room for people to undergo daily activities but with Health protocols [7]. This condition is interesting to see about the public's perception of money politics in the 2020 Concurrent Elections amid the Covid-19 pandemic. 


\section{Methodology}

This paper uses descriptive quantitative research methods conducted by the survey as a data collection technique. The main source of data and information is obtained from respondents as a sample of research using questionnaires or questionnaires as an instrument of data collection, the dissemination of surveys conducted in several cities in Central Java to obtain data and information on voter perception in the political practice of money ahead of the 2020 election.

\section{Results and Discussion}

Organizing elections simultaneously has an important role in the dynamics of democracy in the local realm. It is as mentioned by Agustino that the function of elections is to: (i) give strong legitimacy with the support of real voters, (ii) encourage accountability and responsiveness of regional leaders, (iii) increase awareness and political participation of the people, and (iv) open up opportunities for women to engage in political contestation. The political practice of money in organizing elections both simultaneously and not is a phenomenon of cheating in a democracy that cannot be ignored. The political practice of money has been incarnated into various forms not only limited to the distribution of money but also in the form of the distribution of food or other basic needs assistance. This often makes the perception of the public view that if a candidate's successful team distributes money, then it is considered prohibited. However, when a candidate's spouse provides both assistance in the form of basic needs and others it is often considered something normal. There are two stated views on the goal of giving political money, namely the politics of money targeted to voters who are still undecided in voting (swing voters) and who target their voter base to increase participation in voting that Nichter calls turnout buying [8][9]. This means that the political practice of money is used for two different categories of voters, namely those who are still undecided in deciding the choice and to voters who are already deciding the choice and tend to be loyal. Mapping these voters despite differing characteristics but having the same goal is to obtain votes. This condition shows that the political practice of money provides power relations at the local level that are prone to conflict and cheating [10].

The Election Independence Index (IKP) election 2020 issued by Bawaslu states that the Sub dimension of Power Relations in local elections (Local Political Actors) in Provincial Elections in Indonesia has a level of independence that must be watched out for $(>50.00)$ which one of the sub-dimensions is the mobilization action with intimidation and money politics. This vulnerability that needs to be watched out for is also added to the vulnerability because regional head elections were held during the Covid-19 pandemic. Covid-19 case statistics in Central Java covering 34 districts/cities recorded more than 16,000 positively confirmed patients infected with the virus and more than 1300 confirmed patients died. Covid19 infected patient data is increasing not only harmful to health and economic conditions but also opens a new arena to be used as a political commodity that can be used as a bargaining tool and buy and sell votes. This condition certainly gives an idea that the implementation of the 2020 Concurrent Elections in the pandemic period can be momentum for the flourishing of money political practice to obtain the most votes. It is also a challenge for the organizers of the 2020 concurrent elections so that the election can run smoothly, minimize conflicts in the local realm and run all stages in the Election under the prevailing Health protocols. One more 
important thing is to socialize with various online media and minimize face-to-face socialization [11][12].

Respondents in this paper were drawn from various cities in Central Java with presentations of $56 \%$ earning below Rp 2,600,000.00 with diverse jobs. $28 \%$ of these jobs are students while others are divided into other occupations such as labor, self-employed, civil servants, private employees, freelancers, retirees, and teachers. Research with the spread of surveys already conducted in various cities in Central Java shows that $81 \%$ of respondents to voters said they would still vote in the 2020 Elections to be held in December. Despite the current pandemic, $45 \%$ of respondents expressed interest in following political and governmental developments in Central Java and 24\% expressed interest. This shows that the public's enthusiasm for political issues, especially the 2020 Election, is huge and does not feel threatened by a pandemic. The government's policy to impose a new normal is one of the alternative measures taken to keep the wheels of the economy in society running. But on the other hand, this condition also raises concerns for the public to immediately break the chain of the spread of the Covid-19 virus. The principle in organizing the 2020 concurrent elections is that there are concerns from the organizers that the level of voter participation in this concurrent election will decrease drastically. This concern is not felt very much by the electorate who will vote in the 2020 Concurrent Elections. A total of $43 \%$ of respondents stated that the Covid-19 pandemic did not affect the interest in organizing elections at all and $33 \%$ stated that it was somewhat disturbed to make the mind branch out. This means that the electorate is still thinking about the Covid-19 pandemic but that still does not diminish their interest in seeking information about the 2020 concurrent elections.

The Covid-19 pandemic has influenced interest in the 2020 Pilkada

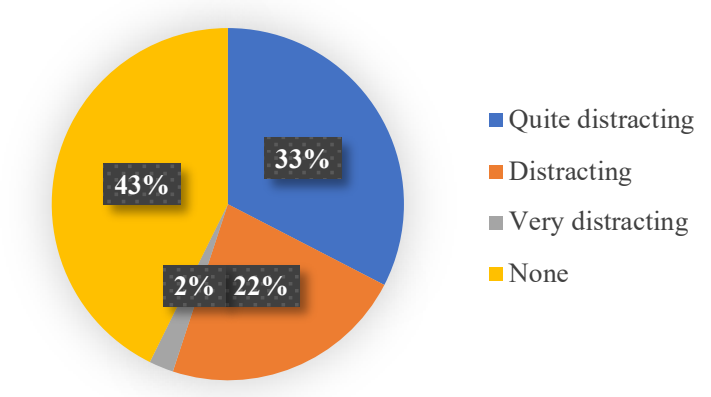

Fig. 1. The Covid-19 pandemic has influenced interest in the 2020 Pilkada.

This was also demonstrated by $44 \%$ of respondents who stated that the Covid-19 pandemic was a bit of a worry but would still exercise its voting rights in the General Election. Based on the data, the implementation of the 2020 concurrent elections amid the Covid-19 pandemic with the implementation of new normal is only a little give a sense of concern for voters and make the receipt of information about the election limited because it also receives info about Covid-19. Thus, the Covid-19 pandemic period in which the number of infected patients is increasing from day to day does not eliminate the sense of interest and desire of the public to continue to exercise their voting rights in the 2020 Elections. In other words, voter participation in the 2020 concurrent elections in the middle of the pandemic is unlikely to experience a drastic decline like what the organizers feared. Still, the enthusiasm of the public in participating in the upcoming 2020 concurrent elections unfortunately $45 \%$ of respondents 
expressed a lack of information about the implementation of this election and $40 \%$ of respondents stated that very little information was obtained related to voting procedures applied using health protocols.

The high participation of voters to exercise their voting rights in the upcoming 2020 concurrent elections certainly provides a positive thing for the implementation of our local democracy. However, this does not mean that there will be no fraud vulnerability during the implementation. The implementation of new normal gives the public a tendency to ignore the spread of the Covid-19 so that it needs supervision of procedures in the stages of organizing elections under health protocols. Another thing that may happen is that the Covid-19 pandemic caused the family economy to decline as a political commodity that was easily able to change people's opinions and viewpoints and assess the political practice of money into something normal. The political practice of money is not only in the form of money distribution but in the current pandemic various forms of the political practice of this money can be found such as the distribution of basic needs as well as the politicization of social assistance that occurred in the period of Covid-19 emergency in several areas. People are particularly vulnerable to being the target of money political practices due to pandemics that led to economic crises such as job cuts, lack of production and sales to small businesses, and the stalled operation of many factories resulting in unemployment. The economic pressure is becoming very potential for the political practice of money.

The view of the increasing political practice of money in the implementation of simultaneous elections in 2020 will also be understood by the electorate. $46 \%$ of respondents replied that the Covid-19 pandemic would encourage and multiply the political practice of money. Some regions in Central Java that will hold elections and have candidates from incumbents can feel advantaged by the condition of this pandemic because it becomes an arena to show a pro attitude towards the community even the regional budget can flow for the activity to be a means to suppress political opponents. For political opponents of the incumbent can also take advantage of this momentum by providing help and other forms of political money for the people to vote for him in the 2020 elections. A total of $57 \%$ of respondents thought that choosing a candidate for the regional head was associated with their record of accomplishment during the pandemic as a consideration in determining the choice.

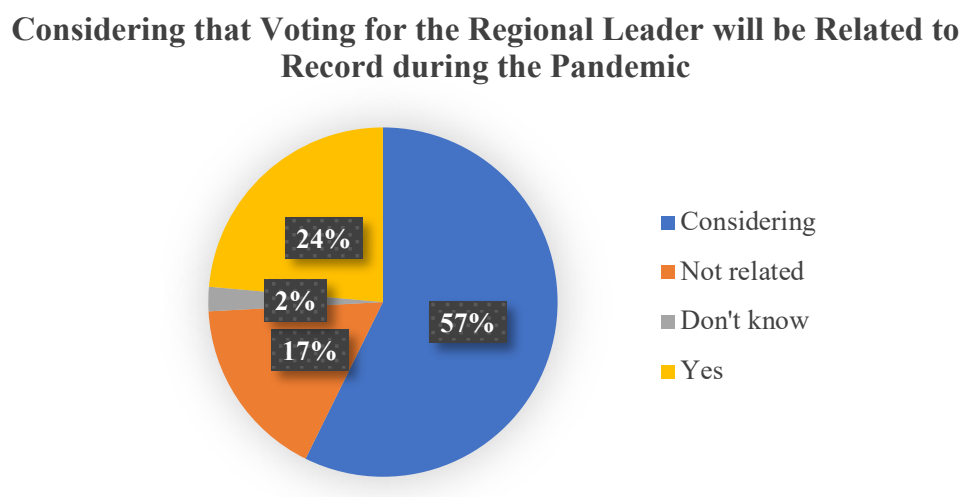

Fig. 2. Considering that Voting for the Regional Leader will be Related to Record during the Pandemic.

The political practice of money doubled in the time leading up to the 2020 election and when the pandemic was also believed by the public to be possible due to the family economic 
crisis stated by $66 \%$ of respondents while as many as $28 \%$ of respondents stated that the political practice of money was done to increase the vote only. That is, the public believes that the guise of providing food due to pandemics is the reason in the political practice of money and this is due to the economic crisis that occurs.

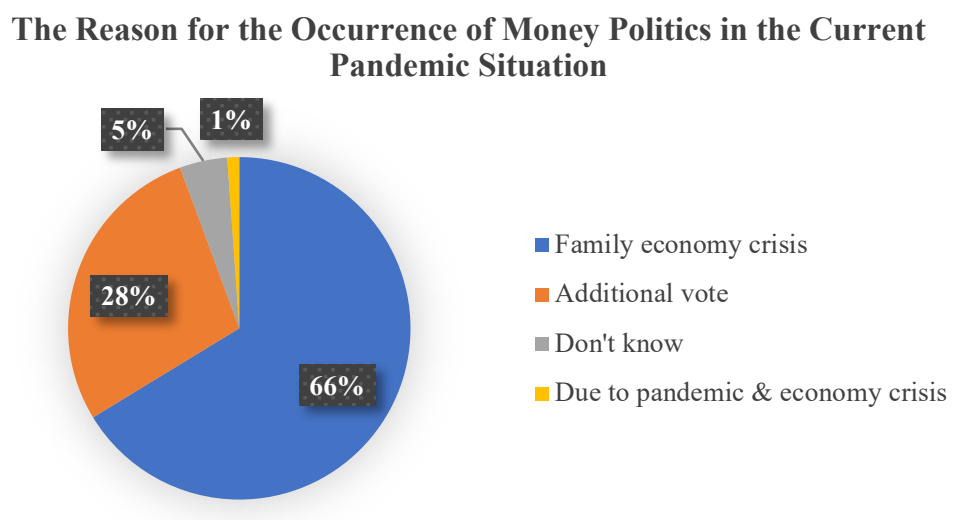

Fig. 3. The Reason for the Occurrence of Money Politics in the Current Pandemic Situation.

The political practice of money can occur in three stages, from before or during the campaign, in quiet times, and in times of election. A total of $26 \%$ of respondents stated that the political practice of money that has occurred in the environment is the distribution of money, and/or food from house to house since before or during the campaign, $25 \%$ of respondents stated the distribution of money, and/or food from house to house ahead of the election and as many as $12 \%$ stated that there was no money politics only promises or vows to be fulfilled at the time of the announcement of the candidate winning the election.

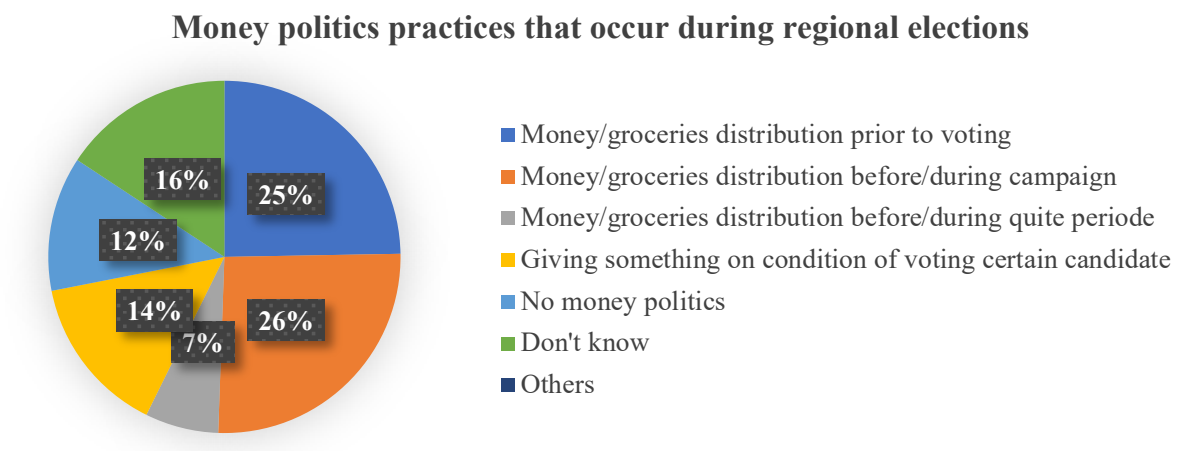

Fig. 4. Money politics practices that occur during regional elections.

There is a public awareness that the practice of money politics is possible even common in the implementation of elections, so the public is divided into two views in response to the condition if it becomes the recipient or target of the political practice of money. The first is a group of people who agree with the assumption that "if there is a division of food/money 
received only, as long as we have a choice that suits our conscience?" $27 \%$ of respondents. While the second group is a community group that disagrees with the assumption. Although the political practice of money is still common in organizing elections, the public still assesses that the performance of supervisory institutions such as Bawaslu has been adequate in performing its role as a supervisor expressed by $65 \%$ of respondents. $52 \%$ of respondents stated that the choice in deciding the choice in the 2020 concurrent elections was not influenced by the political factors of money. It is certainly the hope of all of us that the Covid19 pandemic and the rise of money politics do not make people wrong in choosing their respective regional heads.

\section{Conclusion}

The state of the Covid-19 pandemic did not discourage the interest and desire of the people to continue to exercise their voting rights in the 2020 concurrent elections to be held on December 9. This shows that voter participation in the 2020 concurrent elections is not something to be afraid of. Another thing that needs to be of concern is that the public has realized that the condition of this Covid-19 pandemic has given great space for the political practice of money. The public is aware that the track record of prospective regional heads being considered is one that has a good track record in handling Covid-19. The public also recognizes that the impact of Covid-19 that caused the family economic crisis is a political commodity that can be used as a bargaining chip to win votes. This also opens opportunities for prospective regional heads to compete to attract the public to be able to vote for him by utilizing the momentum of this pandemic. Most of the public believes that the agency's supervision and law enforcement has been adequate in conducting the supervision of the election so far. Therefore, voting procedures and stages in elections that follow the rules of health protocols are expected to be socialized due to the lack of information obtained related to it. Thus, the public has sufficient understanding in understanding the intent and purpose of the political practice of money as a form of vote-buying and selling so that most respondents recognize that the political choice is not determined by the politics of money. High public participation not only has a positive effect on the implementation of the 2020 elections but also becomes a challenge with the increasing political practice of money. What to be aware of is not to let the increasing political practice of money amid the Covid-19 pandemic turn people's political participation into political mobilization.

\section{References}

[1] "Ini 270 Daerah yang Gelar Pilkada Serentak 2020." https://m.detik.com/news/berita/d4596501/ini-270-daerah-yang-gelar-pilkada-serentak-2020 (accessed Jun. 20, 2020).

[2] "Arief Budiman Pilkada di Jawa Tengah Menarik dan Unik." https://jateng.kpu.go.id/2019/12/berita/arief-budiman-pilkada-di-jawa-tengah-menarik-danunik/diakses (accessed Aug. 01, 2020).

[3] R. Dahl, Perihal Demokrasi. Terjemahan. Jakarta: Yayasan Obor Indonesia, 2001.

[4] "Ini 10 Catatan Potensi Permasalahan di Pilkada Serentak." news.detik.com/berita/d3809989/ini-10-catatan-potensi-permasalahan-di-pilkada-serentak (accessed Aug. 01, 2020).

[5] "Bawaslu Temukan 600 Dugaan Politik Uang pada Pilkada 2017." https://nasional.kompas.com/read/2017/02/14/19334401/bawaslu.temukan.600.dugaan.politik.ua ng.pada.pilkada.2017 (accessed Aug. 01, 2020). 
[6] "Virus Corona Jawa Tengah." https://www.kontan.co.id/tag/virus-corona-jawa-tengah (accessed Sep. 01, 2020).

[7] "Daftar Peta Zona Covid-19 Kabupaten/Kota di Jawa Tengah: Semarang, Solo, dan Kudus Zona Merah." https://www.tribunnews.com/regional/2020/09/01/daftar-peta-zona-Covid-19kabupatenkota-di-jawa-tengah-semarang-solo-dan-kudus-zona-merah (accessed Aug. 16, 2020).

[8] L. Agustino, Politik Lokal dan Otonomi Daerah. Bandung: Alphabet, 2017.

[9] S. Stokes, "“Perverse Accountability: A Formal Modelof Machine Politics with Evidence from Argentina"," Am. Polit. Sci. Rev., vol. 99, no. August, pp. 315-325, 2005.

[10] B. Muhtadi, “'Politik Uang Dan Dinamika Elektoral Di Indonesia: Sebuah Kajian Awal Interaksi Antara "Party-Id" Dan Patron-Klien," J. Penelit. Polit., vol. 10, no. June, pp. 41-58, 2013.

[11] Bawaslu, Indeks Kerawanan Pemilu (IKP) Pilkada Serentak 2020. Jakarta Pusat: Bawaslu, 2020.

[12] “Corona Jateng." https://corona.jatengprov.go.id/data (accessed Sep. 02, 2020). 